\title{
Low-molecular-weight hydroxyacids in marine atmospheric aerosol: evidence of a marine microbial origin
}

\author{
Y. Miyazaki, M. Sawano, and K. Kawamura \\ Institute of Low Temperature Science, Hokkaido University, Sapporo, Japan \\ Correspondence to: Y. Miyazaki (yuzom@lowtem.hokudai.ac.jp)
}

Received: 12 March 2014 - Published in Biogeosciences Discuss.: 22 April 2014

Revised: 4 July 2014 - Accepted: 11 July 2014 - Published: 20 August 2014

\begin{abstract}
Lactic acid (LA) and glycolic acid (GA), which are low-molecular-weight hydroxyacids, were identified in the particle and gas phases within the marine atmospheric boundary layer over the western subarctic North Pacific. A major portion of LA $(81 \%)$ and GA $(57 \%)$ was present in the particulate phase, which is consistent with the presence of a hydroxyl group in these molecules leading to the low volatility of the compounds. The average concentration $( \pm \mathrm{SD})$ of LA in more biologically influenced marine aerosols $\left(33 \pm 58 \mathrm{ng} \mathrm{m}^{-3}\right)$ was substantially higher than that in less biologically influenced aerosols $\left(11 \pm 12 \mathrm{ng} \mathrm{m}^{-3}\right)$. Over the oceanic region of phytoplankton blooms, the concentration of aerosol LA was comparable to that of oxalic acid, which was the most abundant diacid during the study period. A positive correlation was found between the LA concentrations in more biologically influenced aerosols and chlorophyll $a$ in seawater $\left(r^{2}=0.56\right)$, suggesting an important production of aerosol LA possibly associated with microbial (e.g., lactobacillus) activity in seawater and/or aerosols. Our finding provides a new insight into the poorly quantified microbial sources of marine organic aerosols (OAs) because such lowmolecular-weight hydroxyacids are key intermediates for OA formation.
\end{abstract}

\section{Introduction}

Ocean-derived organic aerosol $(\mathrm{OA})$ is produced by wave breaking on sea surfaces and/or formed via atmospheric reactions. These particles include high-molecular-weight, partially oxidized biological compounds such as monosaccharides and polysaccharides, fatty acids and alcohols, amines, and amino acids (e.g., Mochida et al., 2002; Facchini et al.,
2008; Russell et al., 2010). The fate of organics in marine aerosols is highly uncertain. Zhou et al. (2008) reported that organic matter $(\mathrm{OM})$ in marine aerosols may act as an important precursor/source and dominant sink for the $\mathrm{OH}$ radical. This leads to the degradation of OM and the production of a series of low-molecular-weight (LMW) organic compounds, which are typically found in water-soluble organic carbon (WSOC) aerosols. However, most WSOC in marine aerosols remains uncharacterized at the molecular level. For example, chemical characterization of submicron marine WSOC over the Atlantic Ocean revealed that uncharacterized organic compounds including organic acids (e.g., mono- and diacids) accounted for more than $50 \%$ of WSOC (Rinaldi et al., 2010).

Organic acids are a ubiquitous component of ambient air (Chebbi and Carlier, 1996). Gas-particle phase partitioning of organic acids is one of the key factors controlling the formation and lifetime of OA. Liu et al. (2012) measured gas and particle phases of formic acid in Los Angeles, CA, and revealed that the observed concentrations of formic acid in the particulate phase were higher than those explained by theory. Yatavelli et al. (2014) measured the phase partitioning of various organic acids in a pine forest using a microorifice volatilization impactor high-resolution time-of-flight chemical ionization mass spectrometer. They suggested that the numbers of carbon and oxygen atoms in species, together with the ambient temperature, control the volatility of organic acids.

Lactic acid (LA) is a monocarboxylic acid with a hydroxyl group adjacent to the carboxyl group. Glycolic acid (GA) is the smallest $\alpha$-hydroxyacid and is highly water-soluble. Ambient hydroxyl monocarboxylic acids including LA and GA have been identified in precipitation (Kieber et al., 2002), 
fog/cloud water (Raja et al., 2008; Sorooshian et al., 2013), and snow pack samples (Kawamura et al., 2012). Fisseha et al. (2004) identified LA in the gas and aerosol phases from photooxidation of 1,3,5-trimethylbenzene in smog chamber experiments. Warneck (2005) investigated the multi-phase chemistry of $C_{2}$ and $C_{3}$ compounds using a box model and suggested that LA, which has no gas-phase sources, is produced in the aqueous phase of clouds under marine atmospheric conditions. Hydroxymonocarboxylic acids are less volatile and can be transformed into oligomers or organosulfates (Claeys et al., 2010; Olson et al., 2011), which may be important pathways for additional sources of OA. However, the abundance, sources, and gas-particle partitioning of such low-molecular-weight hydroxyacids in ambient air are largely unknown.

In this paper, we report for the first time LA and GA in both the particle and gas phases in the ambient atmosphere over the western subarctic North Pacific in summer, where primary production rates are among the highest in the world oceans (Longhurst et al., 1995). We investigate their phase partitioning, possible sources, and the potential processes responsible for their presence in the marine aerosols. Additionally, we discuss the importance of such low-molecularweight hydroxyacids as possible tracers of microbial activity in marine organic aerosols.

\section{Experimental}

\subsection{Aerosol and gas samplings}

Atmospheric sampling was conducted over the subarctic North Pacific from 29 July to 19 August 2008 on board the R/V Hakuho-Maru (KH08-2). Information on the cruise track and back trajectories with average chlorophyll $a$ distributions in surface seawater are given in Miyazaki et al. (2010a). Organic acids in total suspended particulate matter and gas phase were collected at a flow rate of $15 \mathrm{~L} \mathrm{~min}^{-1}$ on the upper deck of the ship. The sampler for organic acids was composed of two-step filters and a filter pack (URG-2000-30FG). Before sample collection, $47 \mathrm{~mm}$ diameter quartz fiber filters were combusted $\left(450^{\circ} \mathrm{C}, 3 \mathrm{~h}\right)$ to remove organic contaminants and stored in a clean glass vial. Particulate organic acids were collected on a quartz fiber filter (first filter), and gaseous-phase organic acids were collected on another quartz filter (second filter) impregnated with potassium hydroxide $(\mathrm{KOH})$ placed downstream of the first filter (Kawamura et al., 1985). It is possible that some particulate-phase organic acids could have evaporated off the first filter and became trapped in the $\mathrm{KOH}$ impregnated filter during sampling. This would have led to underestimation of particulate-phase organic acids, and vice versa for the gas phase. However, the ambient temperature during the sampling period was relatively low $\left(16.8 \pm 4.3^{\circ} \mathrm{C}\right)$, which in general favors phase partitioning into particles, as will be discussed in Sect. 3.2. Therefore, any effect of this possible artifact is thought to have been small. After sample collection, 36 filter samples for gas and particles were stored in the glass vial with a Teflon-lined screw cap at $-20^{\circ} \mathrm{C}$ in a freezer. During the cruise, marine air was drawn for $12-24 \mathrm{~h}$ per sample with no temperature or humidity control.

In addition to the sampler for organic acids, an Andersentype cascade impactor was also used for aerosol sampling to measure methanesulfonic acid (MSA), oxalic acid, and WSOC (Miyazaki et al., 2010b). Possible contamination from the ship exhaust was prevented by shutting off each sampling pumps during beam-side airflow and/or low wind speeds $\left(<5 \mathrm{~m} \mathrm{~s}^{-1}\right)$, resulting in an effective pumping time of $\sim 82 \%$ during the sampling period. At each sampling position along the cruise track, we show the chlorophyll (Chl) $a$ concentrations in the ocean derived from SeaWiFS data, available at NASA's Goddard Space Flight Center/Distributed Active Archive Centers (http://reason.gsfc. nasa.gov/OPS/Giovanni/ocean.aqua.shtml).

\subsection{Chemical analysis of atmospheric samples}

We applied and modified the analytical method given by Kawamura and Kaplan (1984) to determine hydroxymonocarboxylic acids. A filter cut $\left(8.67 \mathrm{~cm}^{2}\right)$ from each sample was extracted with ultra-pure water. The extracts $(15 \mathrm{~mL})$ were then filtrated and adjusted to $\mathrm{pH} 8.5-9.0$ with $0.1 \mathrm{M}$ $\mathrm{KOH}$ (or $0.1 \mathrm{M} \mathrm{HCl}$ ) solution and then concentrated down to $1 \mathrm{~mL}$. The concentrates were transferred onto a cation exchange column $\left(\mathrm{K}^{+}\right.$form). The organic acid anions were eluted with four bed volumes of water into a $25 \mathrm{~mL}$ pearshaped flask and dried using a rotary evaporator and nitrogen blow-down system. Acetonitrile $(4 \mathrm{~mL})$ was added to the flask, followed by $\alpha, p$-dibromoacetophenone $(0.2 \mathrm{M}, 50 \mu \mathrm{L})$ and a dicyclohexyl-18-crown-6 solution $(0.02 \mathrm{M}, 50 \mu \mathrm{L})$ as a catalyst. The flask was stoppered with a ground-glass stopper and a clamp. Esterification of the $\mathrm{RCOO}^{-} \mathrm{K}^{+}$was performed by an ultrasonic bath and placing the flask containing the sample in a warm bath at $80^{\circ} \mathrm{C}$ for $2 \mathrm{~h}$. The reaction mixture was dried with a rotary evaporator and then transferred onto the $\mathrm{SiO}_{2}$ column with $n$-hexane. Excess reagent ( $\alpha, p$-dibromoacetophenone) was first eluted with $10 \mathrm{~mL}$ of $n$-hexane $/ \mathrm{CH}_{2} \mathrm{Cl}_{2}(2: 1, v: v)$. The $p$-bromophenacyl esters of organic acids were eluted into a $2 \mathrm{~mL}$ vial with $2 \mathrm{~mL}$ of $\mathrm{CH}_{2} \mathrm{Cl}_{2} /$ methanol $(95: 5, v: v)$ and then dried in the vial using a nitrogen gas flow.

Furthermore, the $\mathrm{OH}$ functional groups in the phenacyl esters were reacted with $50 \mu \mathrm{L}$ of N,O-bis-(trimethylsilyl) trifluoroacetamide (BSTFA) to form trimethylsilyl (TMS) ethers. The TMS derivatives were then analyzed for the detection of hydroxymonocarboxylic acids using a capillary gas chromatograph (GC: HP GC6890N, Hewlett-Packard, Palo Alto, CA, USA) coupled to a mass spectrometer (MS). Both the carboxyl and the hydroxyl groups within a molecule are derivatized via current analytical methods, which allowed 
identification of the hydroxymonocarboxylic acids (LA and GA) as well as $C_{1}-C_{10}$ monocarboxylic acids. In this paper, we report the concentrations of LA, GA, formic acid $\left(C_{1}\right)$ and acetic acid $\left(C_{2}\right)$. Recoveries of authentic standards spiked on the precombusted quartz fiber filter were $86 \%$ for LA and $90 \%$ for GA. The recoveries for formic and acetic acids were 92 and $93 \%$, respectively. The detection limit for these organic acids was $0.02 \mathrm{ng} \mathrm{m}^{-3}$.

To determine major anions including methanesulfonic acid (MSA) and cations, a piece $\left(1.54 \mathrm{~cm}^{2}\right)$ of the aerosol filter samples obtained by the cascade impactor was extracted with ultra-pure water. The extract $(10 \mathrm{~mL})$ was then filtrated using a membrane disc filter to measure inorganic ions using a Metrohm ion chromatograph (Model 761 compact IC). Oxalic acid and WSOC were measured with quartz filters sampled using a nine-stage cascade impactor (Miyazaki et al., 2010b). A filter cut of $12.56 \mathrm{~cm}^{2}$ was extracted with ultra-pure water and then analyzed for oxalic acid and other dicarboxylic acids using a capillary GC (Hewlett-Packard GC6890N) equipped with a flame ionization detector and GC/MS. The mass concentrations of MSA, oxalic acid, and WSOC reported here were integrated over each stage of the impactor. Because the cascade impactor samples were obtained every $48-72 \mathrm{~h}$, the hydroxyacid data are merged into the cascade impactor data when hydroxyacids are compared with MSA, oxalic acid, and WSOC in this paper.

\section{Results and discussion}

\subsection{Marine biogenic tracers and classification of the samples}

In our previous study (Miyazaki et al., 2010a, b), we used MSA and azelaic acid as marine biological tracers to evaluate the marine biological activity and its contribution to the aerosols obtained during the study period. MSA is known to be produced by the atmospheric oxidation of dimethylsulfide (DMS), which is released as a gas from marine microbial processes. It thus can be used as an indicator of secondary aerosols of marine biological origin. Azelaic acid is derived from the photooxidation of unsaturated fatty acids that are produced by marine phytoplankton and emitted to the atmosphere via the marine microlayer (Mochida et al., 2002).

Based on the concentrations of MSA and azelaic acid in aerosols sampled during the same cruise, Miyazaki et al. (2010a) classified the aerosol samples into two categories: more biologically influenced aerosols (MBAs), composed of 17 samples obtained during 30 July-9 August, and less biologically influenced aerosols (LBAs), composed of 12 samples taken during 9-19 August. Back trajectories suggest that sampled air masses with MBAs were transported within the marine boundary layer (MBL) and frequently encountered oceanic regions with high productivity upwind of the sampling locations. The back trajectory analysis, together with in situ measurements of primary production in seawater, is consistent with the larger abundance of MSA and azelaic acid in MBAs (Miyazaki et al., 2010b).

\subsection{Identification and phase partitioning of low-molecular-weight hydroxyacids}

Figure 1 shows a time series of LA and GA concentrations in the particle and gas phases during the entire cruise. The average concentrations of LA and GA are shown in Table 1 for the MBA and LBA period. Particle-phase LA was found to be 4 times more abundant than gas-phase LA for the MBA period. Similarly, the LA mass in the particle phase was 3 times larger than that in the gas phase for the LBA period. Here the particle-phase fraction $\left(F_{\mathrm{p}}\right)$ of an organic acid is defined as the ratio of the particle-phase concentration to the total $\left(F_{\mathrm{p}}=P /(G+P)\right)$, where $P$ and $G$ are the particle- and gas-phase concentrations, respectively. On average, $F_{\mathrm{p}}$ of LA and GA were 0.81 and 0.57 , respectively, showing that a major portion of these hydroxyacids were present in the particulate phase. In contrast, a major mass fraction of formic acid $\left(F_{\mathrm{p}}=0.04\right)$ and acetic acid $\left(F_{\mathrm{p}}=0.06\right)$ were present in the gas phase (Table 1).

The larger $F_{\mathrm{p}}$ for the measured hydroxyacids can be explained by relatively low vapor pressures of LA $(1.1 \times$ $10^{-4}$ atm at $\left.25^{\circ} \mathrm{C}\right)$ and $\mathrm{GA}\left(5.3 \times 10^{-4}\right.$ atm at $\left.25^{\circ} \mathrm{C}\right)$, which are substantially lower than those of $C_{1}$ and $C_{2}$ monocarboxylic acids (formic acid $=5.6 \times 10^{-2}$ atm and acetic acid $=2.1 \times 10^{-2} \mathrm{~atm}$ at $25^{\circ} \mathrm{C}$ ). The larger fraction of LA and GA in the particle phase is associated with the presence of a hydroxyl group, which leads to the low volatility of the compounds. Indeed, the addition of a hydroxyl group to alkanoic acids is estimated to be effective in reducing saturated mass concentration, thereby increasing the fraction in particulate phase (Yatavelli et al., 2014). Hawkins et al. (2010) performed a positive matrix factorization analysis for submicron particles collected in the southeast Pacific and revealed that the composition of the organic functional group identified as marine sources was dominated by the hydroxyl group (>70\% by mass). The persistence of hydroxyl groups in marine aerosols is consistent with their low volatility.

\subsection{Levels of lactic and glycolic acids in aerosols}

During the entire sampling period, the concentrations of LA in the particulate phase ranged between 0.3 and $216 \mathrm{ng} \mathrm{m}^{-3}$, with an average of $24 \pm 46 \mathrm{ng} \mathrm{m}^{-3}$. The average concentrations of aerosol LA $\left(33 \pm 58 \mathrm{ng} \mathrm{m}^{-3}\right)$ and GA $\left(9 \pm 6 \mathrm{ng} \mathrm{m}^{-3}\right)$ during the MBA period were substantial and significantly larger than those during the LBA period (LA: $11 \pm 12 \mathrm{ng} \mathrm{m}^{-3}$, GA: $5 \pm 3 \mathrm{ng} \mathrm{m}^{-3}$ ). Enhanced concentrations of LA and GA were mostly observed north of $43^{\circ} \mathrm{N}$ (Fig. 1d), where marine biological activity was relatively high (Chl $a>0.5 \mathrm{mg} \mathrm{m}^{-3}$ ). The average concentration of LA was approximately half of the concentration of oxalic acid 
Table 1. Concentrations of lactic, glycolic, formic, and acetic acids together with their particle-phase fraction $\left(F_{\mathrm{p}}\right)$ during the periods when more biologically influenced aerosols (MBAs) and less biologically influenced aerosols (LBAs) were observed aboard the R/V HakuhoMaru. The values are means with standard deviations in parentheses.

\begin{tabular}{|c|c|c|c|c|c|c|}
\hline \multirow[t]{2}{*}{ Period } & \multicolumn{3}{|c|}{$\begin{array}{c}\text { MBA } \\
\text { 30 July-9 August } 2008\end{array}$} & \multicolumn{3}{|c|}{$\begin{array}{c}\text { LBA } \\
\text { 9-19 August } 2008\end{array}$} \\
\hline & Gas* & Particle* & $F_{\mathrm{p}}$ & Gas* & Particle* & $F_{\mathrm{p}}$ \\
\hline Lactic acid & 7.1(7.1) & $33.1(58.4)$ & $0.82(0.27)$ & $3.5(3.0)$ & $10.9(11.7)$ & $0.76(0.31)$ \\
\hline Glycolic acid & $7.9(10.4)$ & $8.5(5.6)$ & $0.52(0.30)$ & $1.4(1.9)$ & $4.8(2.6)$ & $0.77(0.31)$ \\
\hline Formic acid & $56.5(74.9)$ & $3.2(4.6)$ & $0.05(0.23)$ & $52.5(72.9)$ & $1.5(2.0)$ & $0.03(0.27)$ \\
\hline Acetic acid & $141.7(82.4)$ & $10.9(10.2)$ & $0.07(0.25)$ & $101.3(42.0)$ & $4.7(7.2)$ & $0.04(0.06)$ \\
\hline
\end{tabular}

* Units are $\mathrm{ng} \mathrm{m}^{-3}$

( $44 \pm 19 \mathrm{ng} \mathrm{m}^{-3}$ ), which was found to be the most abundant diacid measured during the same cruise (Miyazaki et al., 2010b). In particular, the concentration of LA was comparable to that of oxalic acid on 4-7 August (Fig. 2a), during a period when the ship encountered phytoplankton blooms.

Of the hydroxymonocarboxylic acids, LA and GA have previously been reported in ambient aerosols (Souza et al., 1999; Graham et al., 2002). The concentrations of LA detected over the North Pacific during the MBA period were comparable to those previously observed at pasture and forest sites in Brazil $\left(\sim 10-22 \mathrm{ng} \mathrm{m}^{-3}\right)$ (Graham et al., 2002). GA has been identified in biomass burning aerosols and has also been suggested to be derived from biogenic emissions (Souza et al., 1999). Altieri et al. (2009) suggested that GA and other organic acids detected in rainwater are likely from secondary atmospheric processes and are incorporated during in-cloud or below-cloud scavenging. To our knowledge, LA and GA detected in marine aerosol/gas are reported for the first time, the concentrations of which are comparable to those reported for the terrestrial atmosphere.

\subsection{Possible sources of lactic and glycolic acids in marine aerosols}

In general, the concentrations of LA and GA in the particulate phase displayed similar temporal variations to those of oxalic acid and WSOC (Fig. 2). In particular, the concentrations of LA showed a positive correlation with those of oxalic acid $\left(r^{2}=0.46\right)$, which points to a similar origin of LA and oxalic acid in aerosols. Miyazaki et al. (2010b) suggested that substantial fractions of oxalic acid in MBAs during the same cruise were produced by the degradation of organic precursors emitted by sea spray processes in oceanic regions with high biological productivity. Contributions from anthropogenic sources to the observed LA and GA were unlikely because of the substantially low concentrations of elemental carbon in MBAs $\left(28 \mathrm{ng} \mathrm{m}^{-3}\right)$ and LBAs $\left(54 \mathrm{ng} \mathrm{m}^{-3}\right)$ together with back trajectory analysis (Miyazaki et al., 2010a).

The elevated levels of LA and GA were observed together with high concentrations of chlorophyll $a$ in seawa- ter (Fig. 1a-c), suggesting that the production of LA and GA was associated with marine biota. The concentrations of LA in aerosol and Chl $a$ in seawater displayed a positive correlation $\left(r^{2}=0.40\right)$ as shown in Fig. 3a. The correlation coefficient is higher for the MBA data $\left(r^{2}=0.56\right)$. We can hypothesize that the two most likely formation pathways to account for the presence of LA and GA in the marine atmospheric aerosols are primary emissions of sea spray from the ocean surface and formation by marine microbial and/or photochemical processes (e.g., Vaïtilingom et al., 2013). Several peaks of the $\mathrm{Na}^{+}$concentrations accompanied the enhanced concentrations of LA and GA (e.g., 31 July and 16-18 August). When these spikes are excluded, however, the correlations of LA and GA concentrations with local wind speed and the $\mathrm{Na}^{+}$concentrations are low $\left(r^{2}<0.09\right)$. It should be noted that the positive correlation between the LA (GA) and chlorophyll $a$ did not necessarily depend on the local wind speeds (data not shown). This relationship, together with the lower correlations of the LA and GA with local wind speed and $\mathrm{Na}^{+}$, indicates that primary emissions from the sea surface did not significantly contribute to the observed LA and GA.

Production of LA and GA in aerosol water associated with microbial activity is very likely because some microorganisms produce LA and GA (Kataoka et al., 2001; Raja et al., 2008). Cabredo et al. (2009) reported that LA bacteria (lactobacillus), which produce LA as the major metabolic end product of carbohydrate fermentation, accounted for $\sim 21 \%$ of total airborne bacteria. In fact, the majority of the submicron OA mass over the North Atlantic and Arctic oceans was shown to be composed of carbohydrate-like compounds containing hydroxyl groups from primary emissions of the ocean (Russell et al., 2010). GA can be produced by photorespiration in marine bacteria (Steinberg and Bada, 1984). These previous studies support microbial production of aerosol LA and GA as the product of fermentation of carbohydrates and glycolysis. Moreover, $C_{12}-C_{24}$ monocarboxylic acids are found in marine phytoplankton (e.g., Peltzer and Gagosian, 


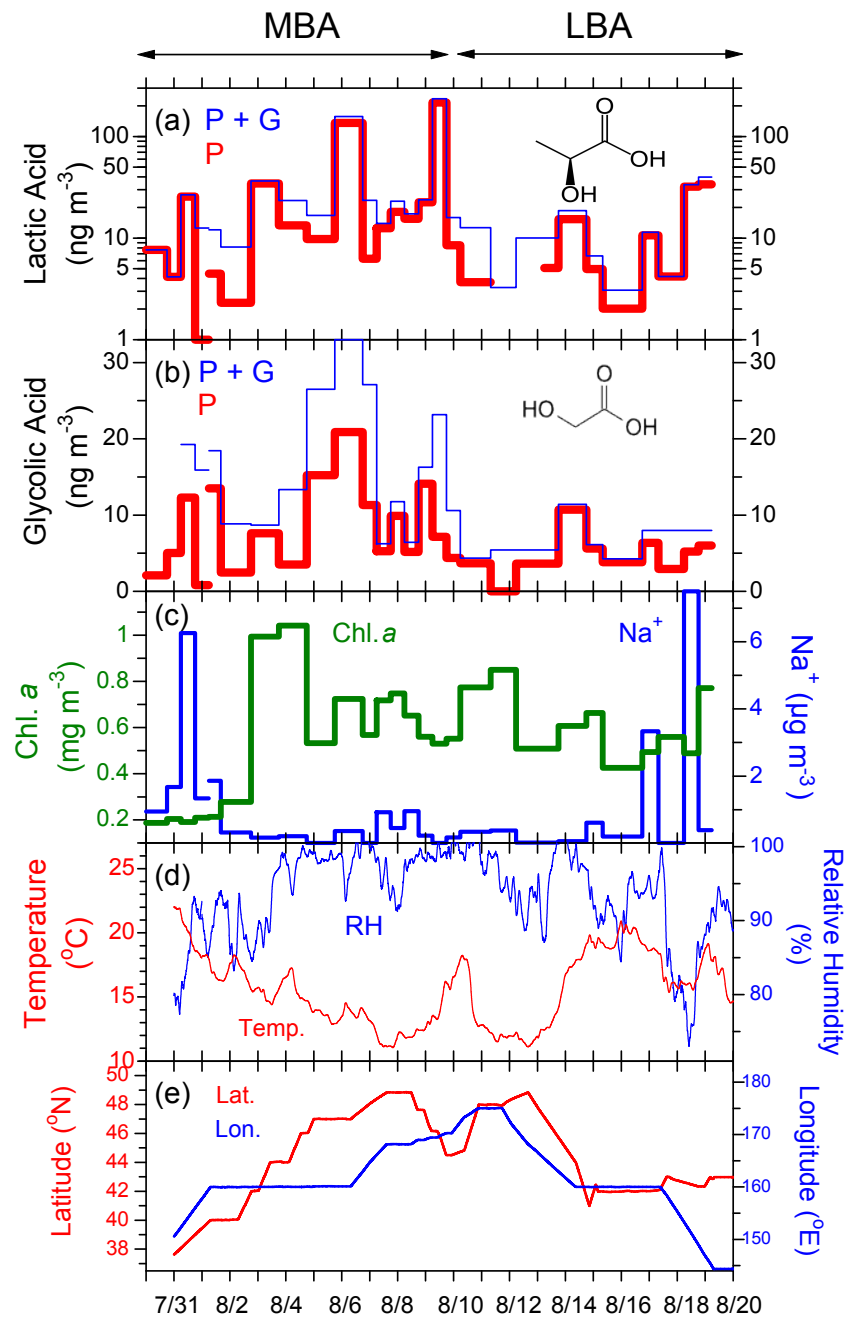

Date (month/day)

Figure 1. Time series of the concentrations of (a) lactic acid and (b) glycolic acid in the particle $(p)$ phase and the sum of gas and particle $(g+p)$ phases, (c) Chl $a$ concentrations in seawater and $\mathrm{Na}^{+}$ concentrations in aerosols, (d) ambient temperature and relative humidity, and (e) the ship position (latitude and longitude) during the R/V Hakuho-Maru cruise. See the text for the definition of MBA (30 July-7 August 2008) and LBA (9-19 August 2008) periods. The $y$ axis of (a) is plotted on a log scale.

1989), and these fatty acids may be degraded to form LA and GA in aerosols after emissions from the sea surface.

It is noted that ambient relative humidity $(\mathrm{RH})$ reached over $85 \%$ during most of the study period, with an average of $94 \pm 6 \%$ (Fig. 1d). The larger concentrations of LA and GA with high $F_{\mathrm{p}}(>0.80)$ were observed at $\mathrm{RH}>90 \%$ (Fig. 4) when aerosol liquid water content (LWC) is sensitive to $\mathrm{RH}$ and is expected to be high (e.g., Liu et al., 2012). High RH (i.e., aerosol LWC) might be favorable to the production of LA and GA in aerosol associated with microbial activity. LA can be further transformed by microbial metabolism to pro-

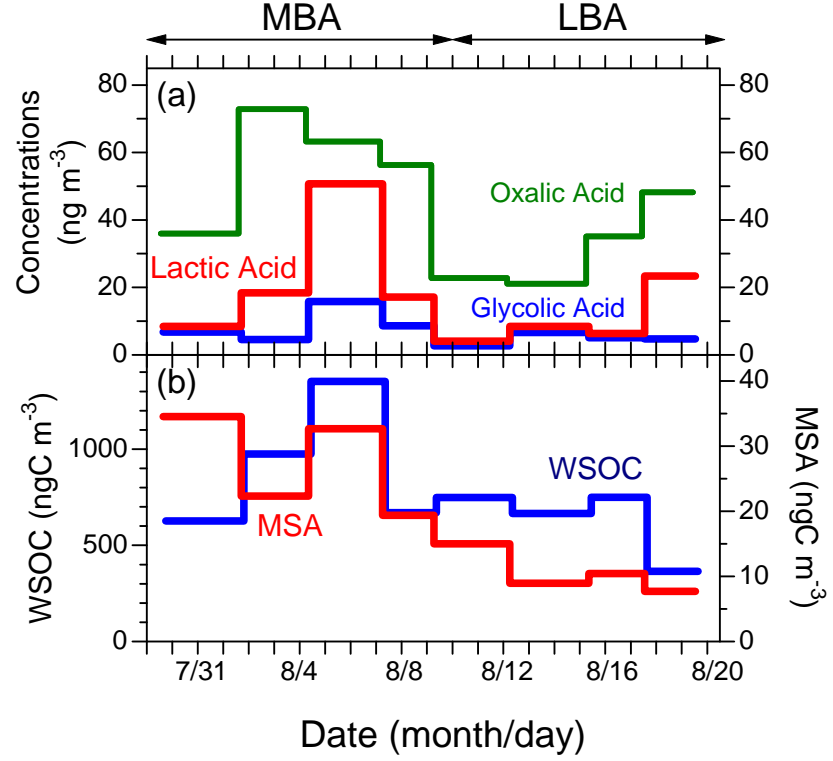

Figure 2. Time series of the concentrations of (a) lactic acid (LA) and glycolic acid (GA) in the particle phase compared with those of oxalic acid, (b) water-soluble organic carbon (WSOC), and methanesulfonic acid (MSA). The duration of LA and GA measurements was averaged over that of oxalic acid, WSOC, and MSA; measurements were performed with a cascade impactor every 2-3 days.
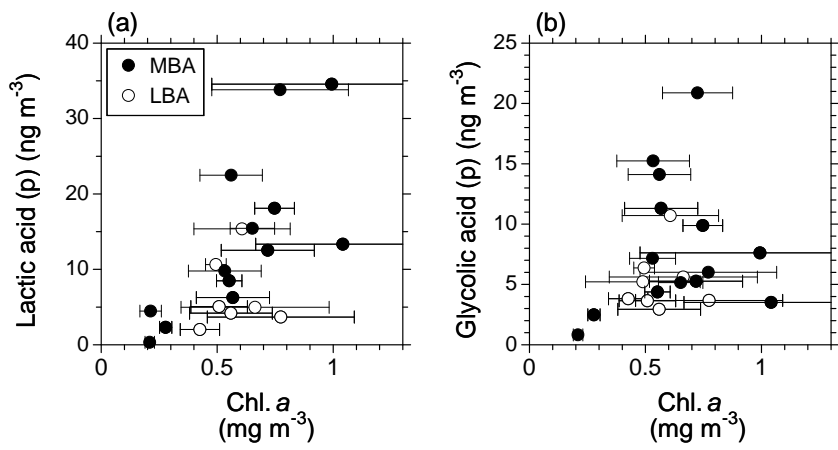

Figure 3. Concentrations of (a) lactic and (b) glycolic acids in the particulate phase as a function of $\mathrm{Chl} a$ concentrations in seawater for more biologically influenced aerosols (MBAs) and less biologically influenced aerosols (LBAs).

duce organic compounds such as pyruvate and lactaldehyde in the case of cloud water (Amato et al., 2007).

The average LA concentration in daytime samples $\left(37 \pm 68 \mathrm{ng} \mathrm{m}^{-3}\right)$ was substantially larger than that in nighttime samples $\left(11 \pm 11 \mathrm{ng} \mathrm{m}^{-3}\right)$. The difference in the concentrations suggests that LA was likely to be formed locally over the oceanic region, although the exact mechanism is not clear. In fact, LA with higher concentrations in daytime than nighttime was also reported for rain samples (Avery et al., 2001). In contrast, the difference between daytime concentrations $\left(7 \pm 4 \mathrm{ng} \mathrm{m}^{-3}\right)$ and nighttime concentrations 

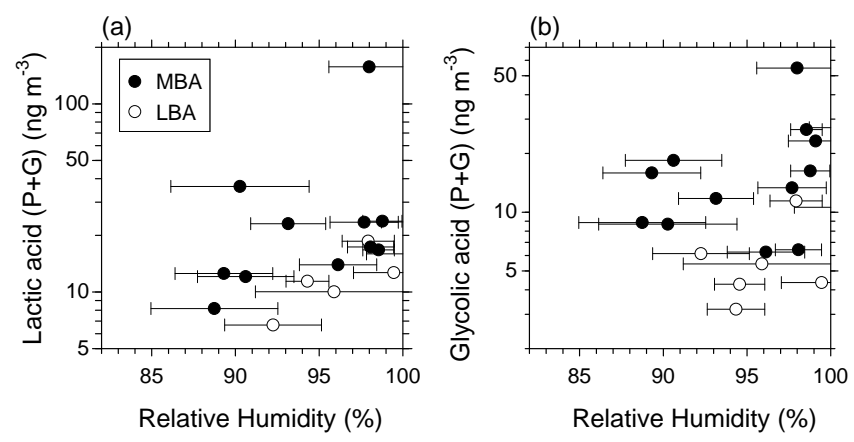

Figure 4. Concentrations of (a) lactic and (b) glycolic acids in the gas and particle $(g+p)$ phases as a function of relative humidity for MBAs and LBAs. The $y$ axis is plotted on a log scale.

$\left(6 \pm 4 \mathrm{ng} \mathrm{m}^{-3}\right)$ of GA was rather small. Moreover, the correlation between the concentrations of GA and in situ chlorophyll $a\left(r^{2}=0.10\right)$ was less significant (Fig. 3b). These results indicate that formation processes of GA including the timescale are different from those of LA, and that GA may have been also produced during the transport to the sampling location, precursors of which were emitted over oceanic region upwind.

In summary, our data point to formation processes for LA and GA in the aerosol from marine biota, most likely associated with marine microbial activity as well as photochemistry. Although we did not identify the types of microbes such as bacteria (e.g., Burrows et al., 2009; DeLeon-Rodriguez et al., 2013) which may contribute to the production of LA and GA, the detailed mechanisms of the production associated with microbial activity should be investigated in future studies. LA, GA, and other hydroxyacids can be involved in acid- or radical-catalyzed esterification of organic acids, which leads to the production of oligomers (Altieri et al., 2009). Therefore, we propose that these low-molecularweight hydroxyacids detected in the biologically influenced marine aerosols are key intermediates for understanding the additional sources of marine OA. Our finding highlights the importance of hydroxyacids in marine aerosols produced by marine microbial processes, which may be involved in the formation of cloud particles in the marine atmosphere.

\section{Conclusions}

Particle and gas phases of LA and GA were identified in marine atmospheric samples obtained in the MBL over the western subarctic North Pacific. On average, 81 and $57 \%$ of the LA and GA mass, respectively, were present in the particulate phase. The large fraction of the particulate phase is attributable to the presence of a hydroxyl group in these molecules lowering the volatility of these hydroxyacids. The average concentration of LA in more biologically influenced marine aerosols $\left(33 \pm 58 \mathrm{ng} \mathrm{m}^{-3}\right)$ was substan- tially higher than that in less biologically influenced aerosols $\left(11 \pm 12 \mathrm{ng} \mathrm{m}^{-3}\right)$. Over the oceanic region of phytoplankton blooms, the concentration of LA in aerosol was comparable to that of oxalic acid. We found a positive correlation of the LA concentrations in aerosols with Chl $a$ in seawater and ambient relative humidity, suggesting an important production of aerosol LA possibly associated with microbial activity. Our finding provides a new insight into the poorly quantified microbial sources of marine OA. The finding points to the importance of ocean-derived low-molecular-weight hydroxyacids, which are key intermediates for OA formation in the marine atmosphere.

Acknowledgements. We acknowledge M. Uematsu for organizing the R/V Hakuho-Maru (KH08-2) cruise. We also thank the crew of the ship and all the scientists on board for their support during the cruise. This research was supported by a Grant-in-Aid for Scientific Research from the Ministry of Education, Culture, Sports, Science and Technology, Japan.

Edited by: K. Suzuki

\section{References}

Altieri, K. E., Turpin, B. J., and Seitzinger, S. P.: Oligomers, organosulfates, and nitrooxy organosulfates in rainwater identified by ultra-high resolution electrospray ionization FTICR mass spectrometry, Atmos. Chem. Phys., 9, 2533-2542, doi:10.5194/acp-9-2533-2009, 2009.

Amato, P., Demeer, F., Melaouhi, A., Fontanella, S., Martin-Biesse, A.-S., Sancelme, M., Laj, P., and Delort, A.-M.: A fate for organic acids, formaldehyde and methanol in cloud water: their biotransformation by micro-organisms, Atmos. Chem. Phys., 7, 4159-4169, doi:10.5194/acp-7-4159-2007, 2007.

Avery, G. B., Willey, J. D., and Kieber, R. J.: Diurnal variations in major rainwater components at a coastal site in North Carolina, Atmos. Environ., 35, 3927-3933, 2001.

Burrows, S. M., Elbert, W., Lawrence, M. G., and Pöschl, U.: Bacteria in the global atmosphere - Part 1: Review and synthesis of literature data for different ecosystems, Atmos. Chem. Phys., 9, 9263-9280, doi:10.5194/acp-9-9263-2009, 2009.

Cabredo, S., Parra, A., Saenz, C., and Anzano, J.: Bioaerosols chemometric characterization by laser-induced fluorescence: air sample analysis, Talanta, 77, 1837-1842, doi:10.1016/j.talanta.2008.10.030, 2009.

Chebbi, A. and Carlier, P.: Carboxylic acids in the troposphere, occurrence, sources, and sinks: A review, Atmos. Environ., 30, 4233-4249, doi:10.1016/1352-2310(96)00102-1, 1996.

Claeys, M., Wang, W., Vermeylen, R., Kourtchev, I., Chi, X., Farhat, Y., Surratt, J. D., Gómez-González, Y., Sciare, J., and Maenhaut, W.: Chemical characterisation of marine aerosol at Amsterdam Island during the austral summer of 2006-2007, J. Aerosol Sci., 41, 13-22, doi:10.1016/j.jaerosci.2009.08.003, 2010.

DeLeon-Rodriguez, N., Lathem, T. L., Rodriguez-R, L. M., Barazesh, J. M., Anderson, B. E., Beyersdorf, A. J., Ziemba, L. D., Bergin, M., Nenes, A., and Konstantinidis, K. T.: Microbiome of the upper troposphere: Species composition and prevalence, 
effects of tropical storms, and atmospheric implications, P. Natl. Acad. Sci., 110, 2575-2580, doi:10.1073/pnas.1212089110, 2013.

Facchini, M. C., Decesari, S., Rinaldi, M., Carbone, C., Finessi, E., Mircea, M., Fuzzi, S., Moretti, F., Tagliavini, E., Ceburnis, D., and O'Dowd, C. D.: Important source of marine secondary organic aerosol from biogenic amines, Environ. Sci. Technol., 42, 9116-9121, doi:10.1021/es8018385, 2008.

Fisseha, R., Dommen, J., Sax, M., Paulsen, D., Kalberer, M., Maurer, R., Höfler, F., Weingartner, E., and Baltensperger, U.: Identification of organic acids in secondary organic aerosol and the corresponding gas phase from chamber experiments, Anal. Chem., 76, 6535-6540, doi:10.1021/ac048975f, 2004.

Graham, B., Mayol-Bracero, O. L., Guyon, P., Roberts, G. C., Decesari, S., Facchini, M. C., Artaxo, P., Maenhaut, W., Köll, P., and Andreae, M. O.: Water-soluble organic compounds in biomass burning aerosols over Amazonia 1. Characterization by NMR and GC-MS, J. Geophys. Res., 107, 8047, doi:10.1029/2001JD000336, 2002.

Hawkins, L. N., Russell, L. M., Covert, D. S., Quinn, P. K., and Bates, T. S.: Carboxylic acids, sulfates, and organosulfates in processed continental organic aerosol over the southeast $\mathrm{Pa}$ cific Ocean during VOCALS-REx 2008, J. Geophys. Res., 115, D13201, doi:10.1029/2009JD013276, 2010.

Kataoka, M., Sasaki, M., Hidalgo, A.-R. G. D., Nakano, M., and Shimizu, S.: Glycolic acid production using ethylene glycoloxidizing microorganisms, Biosci. Biotechnol. Biochem., 65, 2265-2270, doi:10.1271/bbb.65.2265, 2001.

Kawamura, K. and Kaplan, I. R.: Capillary gas chromatography determination of volatile organic acids in rain and fog samples, Anal. Chem., 56, 1616-1620, doi:10.1021/ac00273a018, 1984.

Kawamura, K., Ng, L.-L., and Kaplan, I. R.: Determination of organic acids $\left(\mathrm{C}_{1}-\mathrm{C}_{10}\right)$ in the atmosphere, motor exhausts, and engine oils, Environ. Sci. Technol., 19, 1082-1086, doi:10.1021/es00141a010, 1985.

Kawamura, K., Matsumoto, K., Tachibana, E., and Aoki, K.: Low molecular weight $\left(\mathrm{C}_{1}-\mathrm{C}_{10}\right)$ monocarboxylic acids, dissolved organic carbon and major inorganic ions in alpine snow pit sequence from a high mountain site, central Japan, Atmos. Environ., 62, 272-280, doi:10.1016/j.atmosenv.2012.08.018, 2012.

Kieber, R. J., Peake, B., Willey, J. D., and Avery, G. B.: Dissolved organic carbon and organic acids in coastal New Zealand rainwater, Atmos. Environ., 36, 3557-3563, doi:10.1016/S13522310(02)00273-X, 2002.

Liu, J., Zhang, X., Parker, E. T., Veres, P. R., Roberts, J. M., de Gouw, J. A., Hayes, P. L., Jimenez, J. L., Murphy, J. G., Ellis, R. A., Huey, G. L., and Weber, R. J.: On the gas-particle partitioning of soluble organic aerosol in two urban atmospheres with contrasting emissions: 2. gas and particle phase formic acid, J. Geophys. Res., 117, D00V21, doi:10.1029/2012JD017912, 2012.

Longhurst, A., Sathyendranath, S., Platt, T., and Caverhill, C.: An estimate of global primary production in the ocean from satellite radiometer data, J. Plankton Res., 17, 1245-1271, doi:10.1093/plankt/17.6.1245, 1995.

Miyazaki, Y., Kawamura, K., and Sawano, M.: Size distributions of organic nitrogen and carbon in remote marine aerosols: Evidence of marine biological origin based on their isotopic ratios, Geophys. Res. Lett., 37, L06803, doi:10.1029/2010GL042483, 2010a.
Miyazaki, Y., Kawamura, K., and Sawano, M.: Size distributions and chemical characterization of water-soluble organic aerosols over the western North Pacific in summer, J. Geophys. Res., 115, D23210, doi:10.1029/2010JD014439, 2010b.

Mochida, M., Kitamori, Y., Kawamura, K., Nojiri, Y., and Suzuki, $\mathrm{K}$. .: Fatty acids in the marine atmosphere: Factors governing their concentrations and evaluation of organic films on sea salt particles, J. Geophys. Res., 107, 4325, doi:10.1029/2001JD001278, 2002.

Olson, C. N., Galloway, M. M., Yu, G., Hedman, C. J., Lockett, M. R., Yoon, T., Stone, E. A., Smith, L. M., and Keutsch, F. N.: Hydroxycarboxylic acid-derived organosulfates: synthesis, stability, and quantification in ambient aerosol, Environ. Sci. Technol., 45, 6468-6474, doi:10.1021/es201039p, 2011.

Peltzer, E. T. and Gagosian, R. B.: Organic geochemistry of aerosols over the Pacific Ocean, in: Chemical Oceanography, 10, guest editor: Duce, R. A., edited by: Riley, J. P. and Chester, R., 281338, Academic Press, London, 1989.

Raja, S., Raghunathan, R., Yu, X.-Y., Lee, T., Chen, J., Kommalapati, R. R., Murugesan, K., Shen, X., Qingzhong, Y., Valsaraj, K. T., and Collett Jr., J. L.: Fog chemistry in the TexasLouisiana Gulf Coast corridor, Atmos. Environ., 42, 2048-2061, doi:10.1016/j.atmosenv.2007.12.004, 2008.

Rinaldi, M., Decesari, S., Finessi, E., Giulianelli, L., Carbone, C., Fuzzi, S., O’Dowd, C. D., Ceburnis, D., and Facchini, M. C.: Primary and secondary organic marine aerosol and oceanic biological activity: Recent results and new perspectives for future studies, Adv. Meteorol., 2010, 310682, doi:10.1155/2010/310682, 2010.

Russell, L. M., Hawkins, L. N., Frossard, A. A., Quinn, P. K., and Bates, T. S.: Carbohydrate-like composition of submicron atmospheric particles and their production from ocean bubble bursting, P. Natl. Acad. Sci. USA, 107, 15, 6652-6657, doi:10.1073/pnas.0908905107, 2010.

Sorooshian, A., Wang, Z., Coggon, M. M., Jonsson, H. H., and Ervens, B.: Observations of sharp oxalate reductions in stratocumulus clouds at variable altitudes: organic acid and metal measurements during the 2011 EPEACE Campaign, Environ. Sci. Technol., 47, 7747-7756, doi:10.1021/es4012383, 2013.

Souza, S. R., Vasconcellos, P. C., and Carvalho, L. R. F.: Low molecular weight carboxylic acids in an urban atmosphere: Winter measurements in São Paulo City, Brazil, Atmos. Environ., 33, 2563-2574, doi:10.1016/S1352-2310(98)00383-5, 1999.

Steinberg, S. M. and Bada, J. L.: Oxalic, glyoxalic and pyruvic acids in eastern Pacific Ocean waters, J. Mar. Res., 42, 697-708, doi:10.1357/002224084788506068, 1984.

Vaïtilingom, M., Deguillaume, L., Vinatier, V., Sancelme, M., Amato, P., Chaumerliac, N., and Delort, A.-M.: Potential impact of microbial activity on the oxidant capacity and organic carbon budget in clouds, P. Natl. Acad. Sci. USA, 110, 559-564, doi:10.1073/pnas.1205743110, 2013.

Warneck, P.: Multi-phase chemistry of $\mathrm{C}_{2}$ and $\mathrm{C}_{3}$ organic compounds in the marine atmosphere, J. Atmos. Chem., 51, 119-159, doi:10.1007/s10874-005-5984-7, 2005.

Yatavelli, R. L. N., Stark, H., Thompson, S. L., Kimmel, J. R., Cubison, M. J., Day, D. A., Campuzano-Jost, P., Palm, B. B., Hodzic, A., Thornton, J. A., Jayne, J. T., Worsnop, D. R., and Jimenez, J. L.: Semicontinuous measurements of gas-particle partitioning of organic acids in a ponderosa pine forest using a MOVI-HRToF- 
CIMS, Atmos. Chem. Phys., 14, 1527-1546, doi:10.5194/acp14-1527-2014, 2014.
Zhou, X., Davis, A. J., Kieber, D. J., Keene, W. C., Maben, J. R., Maring, H., Dahl, E. E., Izaguirre, M. A., Sander, R., and Smoydzyn, L.: Photochemical production of hydroxyl radical and hydroperoxides in water extracts of nascent marine aerosols produced by bursting bubbles from Sargasso seawater, Geophys. Res. Lett., 35, L20803, doi:10.1029/2008GL035418, 2008. 